\title{
Áhrif hvata á störf lækna
}

\author{
Una Jónsdóttir, hagfræđingur, meistaranemi við Humboldt háskólann í \\ Berlín og Tinna Laufey Ásgeirsdóttir, hagfræđingur, lektor við Hagfræđi- \\ deild Háskóla Íslands
}

\begin{abstract}
Útdráttur
Rannsóknir á raungögnum benda til pess að fólk bregðist við hvötum. Slíkt viðbragð er pó mismikið við mismunandi aðstæður. Í pessari grein eru áhrif mismunandi greiðslufyrirkomulags á störf lækna skoðuð. Ferliverkasamningar sem voru tímabundið við lýði á Landspítala - háskólasjúkrahúsi eru teknir til skoðunar, saga peirra er rakin og varpað ljósi á hvaða áhrif afnám peirra hefur haft á samfélagið. Mældar voru hlutfallslegar líkur á að sjúklingum væri vísað í speglun eftir að ferliverkasamningar féllu úr gildi, samanborið við pegar peir voru í gildi. Tíðni speglana árin 2000-2002 var borin saman við tíðni speglana árin 2003-2005. Gögn fengust frá Landspítala við Hringbraut par sem speglanir voru flokkaðar eftir tegundum yfir tímabilið. Frá Landspítala í Fossvogi fengust aðeins tölur um heildarspeglanir á ári úr starfsemisupplýsingum spítalans. Frá Sjúkratryggingum Íslands fengust tölur yfir mismunandi speglanir framkvæmdar á einkastofum lækna á tímabilinu og að lokum fengust, til samanburðar, sambærilegar tölur frá Sjúkrahúsinu á Akureyri. Á Akureyri átti engin breyting sér stað í greiðslutilhögun til lækna á tímabilinu. Niðurstöður sýndu að á einkastofum voru 185\% meiri líkur á að einstaklingar færu í meltingavegs- og berkjuspeglun eftir að ferliverkasamningum lauk, en á Landspítalanum minnkuðu líkurnar á speglun um 38,2\%. Hlutfallsleg hætta á að einstaklingum væri vísað í speglun á höfuðborgarsvæðinu heilt á litið jókst en líkurnar voru 3,57\% meiri á speglun eftir að ferliverkasamningum lauk. Metin tengsl breytinga á greiðslufyrirkomulagi og speglanatíðni eru töluverð, bæði hvað varðar tölfræðilega marktækni og stærð áhrifanna, sem geta tæpast talist smávægileg.
\end{abstract}

Efnisorð: Greiðslufyrirkomulag, heilbrigðispjónusta, hvatar, speglanir.

\author{
Icelandic Review of Politics and Administration Vol. 9, Issue 1 (101-112) \\ (c) 2013 Contact: Tinna Laufey Ásgeirsdottir, ta@hi.is \\ Article first published online June 26th 2013 on http://www.irpa.is \\ Publisher: Institute of Public Administration and Politics, Gimli, Sæmundargötu 1, 101 Reykjavík, Iceland \\ Stjórnmál \& stjórnsýsla 1. tbl. 9. árg. 2013 (101-112) Fræđigreinar \\ (C) 2013 Tengiliður: Tinna Laufey Ásgeirsdottir, ta@hi.is \\ Vefbirting 26. júní 2013 - Birtist á vefnum http://www.stjornmalogstjornsysla.is \\ Útgefandi: Stofnun stjórnsýslufræða og stjórnmála, Gimli, Sæmundargötu 1, 101 Reykjavík \\ DOI: http://dx.doi.org/10.13177/irpa.a.2013.9.1.5 \\ This work is licensed under a Creative Commons Attribution 3.0 License.
}




\title{
The Impact of Incentives on Physician Practices
}

\begin{abstract}
Theoretical economics and empirical results indicate that people respond to incentives. However, the magnitude of those responses differs according to behavior and context. We investigated the effect of contracts for ambulatory-care services temporarily in effect at Landspitali - The National University Hospital of Iceland on physicians' practices. The relative risk of endoscopy referrals was calculated after per-referral compensations were eliminated, versus when they were in effect. The frequency of endoscopies during the years of 2000-2002 was compared to the frequency of endoscopies in the years 2003-2005. Data was collected from the University Hospital at Hringbraut (LSH-Hringbrant) along with the University Hospital in Fossvogur (LSH-Fossvogi). Data was also collected from The Icelandic Health Insurance (Sjúkratryggingar Islands) on endoscopies preformed at physicians' private clinics. For comparison, analogous data was collected from Akureyri Hospital where no change in physician compensations occurred over the time period. The results showed a $185 \%$ increased chance of referrals to an endoscopy at private physicians' offices after the contracts on ambulatory care services were eliminated. At the University Hospital however, these chances decreased by $38.2 \%$. The overall relative risk of being referred to an endoscopy in the capital region increased by $3.57 \%$ after the contracts were eliminated. The assessed relationship between changes in payment schedules to physicians and the frequency rate of endoscopies is statistically, as well as practically significant.
\end{abstract}

Keywords: Payments, Health Care, Incentives, Endoscopies.

\section{Inngangur}

Markaður fyrir heilbrigðispjónustu er um margt óvenjulegur. Ein af grunnforsendum fullkomins markaðar er að neytendur hafi fullkomnar upplýsingar um vörur, gæði og verð en slíkt á eðli málsins samkvæmt ekki við pegar um sérfræðipekkingu er að ræða. Til að geta metið gildi pekkingarinnar, purfum við að öðlast pekkinguna (Arrow, 1963). pví verður til markaðsbrestur við úthlutun heilbrigðispjónustu par sem kaupendur og seljendur eru með ósamhverfar upplýsingar um vöruna. Við slíkar aðstæður er hætta á að frjáls markaður stuðli ekki að pjóðhagslega hagkvæmastri niðurstöðu par sem gæðin leita ekki sjálfkrafa pangað sem best not eru fyrir pau í pví magni sem hámarkar hagsæld. Vandinn er pó sá að hámörkun hags að gefnu tilliti til takmarkaðra auðlinda getur einnig verið hinu opinbera erfið og miklu máli skiptir við opinbera stefnumótun í heilbrigðismálum að tekið sé tillit til áhrifa hvata á veitt magn pjónustu.

Kaupendur og seljendur heilbrigðispjónustu búa ekki yfir jafngildum upplýsingum um pjónustuna sem gerir раð að verkum að læknar hafa vald yfir sjúklingum sínum î krafti sérpekkingar sinnar. Læknar geta nýtt ósamhverfar upplýsingar milli sín og sjúk- 


\section{STJÓRNMÁL \& \\ STJÓRNSÝSLA}

lings sér til hagsbóta með misjöfnum hætti eftir pví hvernig greiðslufyrirkomulagi til peirra er háttað. Ef læknar fá föst laun geta peir nýtt sér ósamhverfu upplýsingarnar til pess að draga úr eftirspurn, en ef peir fá greitt í samræmi við unnin verk geta peir nýtt sér ósamhverfu upplýsingarnar til pess að hvetja til eftirspurnar.

Finna má vísbendingar um ónauðsynlegar aðgerðir. Bandarísk gögn sýna til dæmis að í peim fylkjum par sem eytt er meiri fjármunum í heilbrigðispjónustu en í öðrum fylkjum er vart um betri heilbrigðispjónustu að ræða (Dartmouth Atlas of Health Care (e.d.)). Munurinn á pjónustu við sjúklinga eftir pví hvort læknar fá greidd föst laun eða í samræmi við unnin verk er einnig vísbending um að einhver læknisverk gætu verið ónauðsynleg (Pauly, 1979).

Í pessari rannsókn eru áhrif greiðslufyrirkomulags til lækna á fjölda unninna verka skoðuð. Ferliverkasamningar sem voru tímabundið í gildi á Landspítalanum verða til umfjöllunar, en samkvæmt peim fengu læknar greitt í samræmi við unnin verk á göngudeildum en eftir að ferliverkasamningar voru felldir úr gildi fengu læknar eingöngu föst laun. Ætlunin er að skoða hvaða áhrif petta greiðslufyrirkomulag hafði á fjölda unninna verka á göngudeildum. Litið var sérstaklega á meltingavegs- og berkjuspeglanir á tímabilinu 2000-2005 og reiknuð hlutfallsleg áhætta (relative risk) pess að einstaklingur færi í speglun eftir að ferliverkasamningar féllu úr gildi, samanborið við pegar peir voru í gildi.

раð er ekki ætlun okkar að svara pví með óyggjandi hætti hér hvort mæld breyting á pjónustunni sé betri eða verri fyrir pjóðfélagið, heldur einungis að varpa ljósi á áhrif greiðslufyrirkomulagsins á starfshætti lækna. Раð er mikilvægt að skoða áhrif greiðslukerfa við margvíslegar aðstæður, en rannsókn sem pessi hefur ekki farið fram á íslenskum gögnum áður. Niðurstöður pessarar rannsóknar sýna að fjöldi speglana sem framkvæmdar voru á Landspítala dróst saman eftir afnám ferliverkasamninganna en jókst að sama skapi á einkastofum. Í heildina jókst hlutfallsleg hætta á að sjúklingar færu í speglun á höfuðborgarsvæðinu lítillega.

Eftir sameiningu Borgarspítalans og Landakotsspítala í Sjúkrahús Reykjavíkur, var innleitt kerfi einstaklingsbundinna samninga við hvern og einn lækni um pað hversu mikið hlutfall vinnunnar hjá peim færi í að sinna göngudeildarverkum par sem peir fengju greitt í samræmi við unnin verk. •á varð til pað sem kallast ferliverkasamningar. Ferliverk voru skilgreind af heilbrigðis- og tryggingamálaráðuneytinu sem öll sú læknismeðferð sem ekki krefðist innlagnar á sjúkrahús (Landspítali - háskólasjúkrahús, 2001). Í orðræðu manna hafa ferliverk pó oft verið skilgreind sem pau verk sem sérstaklega er greitt fyrir par sem ferliverkin voru að mestu leyti framkvæmd á göngudeild par sem greiðslutilhögunin var með peim hætti. Рað skal pví tekið fram að pær speglanir sem hér eru til skoðunar eru ekki speglanir á inniliggjandi sjúklingum. Verkin voru fjármögnuð með yfirfærslum fjárveitinga frá TR eða öðrum til LSH. Læknar greiddu aðstöðugjald og tíminn sem fór í að sinna ferliverkum var dreginn frá tímunum sem fóru í að sinna öðrum verkum á spítalanum (Landspítali - háskólasjúkrahús, 2001).

Árið 1998 voru gerðar pær grundvallarbreytingar í samningum sérfræðilækna við TR að peim var heimilað að setja upp skurðstofur eða aðra vinnuaðstöðu utan sjúkrahúsa og 


\section{STJÓRNSÝSLA}

vinna læknisverk sín par (Ríkisendurskoðun, 2002). Einkastofurekstur jókst í kjölfarið, og greiddum læknisverkum fjölgaði á árinu 1998 og hefur fjölgað jafnt og pétt síðan pá (Landspítali - háskólasjúkrahús, 2001).

Í desember 2002 ákvað stjórn spítalans að allir starfsmenn spítalans sem gegndu yfirmannsstöðu skyldu vera í fullu starfi og mættu peir ekki sinna neinum störfum utan hans nema kennslu á háskólastigi og setu í opinberum nefndum og ráđum (Landspítali - háskólasjúkrahús, 2005). Sérstakar greiðslur til yfirmanna vegna vinnu við ferliverk skyldu afnumdar og laun fyrir göngudeildarvinnu á LSH skyldu greidd samkvæmt kjarasamningum viðkomandi starfstéttar (Landspítali - háskólasjúkrahús, 2004). Nýir kjarasamningar voru gerðir par sem helgunarákvæðin féllu brott en í stað pess var ákveðið að peir læknar sem helguðu spítalanum vinnu sína fengju að vera í 100\% starfi á LSH en peir sem voru í stofurekstri máttu ekki vera í meira en 80\% starfi (Morgunbladid, 2004).

Hegðun lækna breytist töluvert eftir pví hvort peir fá greitt í samræmi við unnin verk eða fá föst laun fyrir hvern sjúkling óháð meðferðinni sem er veitt (Ellis, 1998). Fyrirkomulag par sem greitt er í samræmi við unnin störf kemur sér vel fyrir sjúklinga sem eru mjög veikir, pað er líklegt að peir muni fá skjóta meðferð par sem gera verður ráð fyrir pví að læknar vilji í slíkum tilfellum bjóða upp á mikla pjónustu. Fastlaunakerfi á að koma í veg fyrir að læknar hvetji til óparfrar eftirspurnar par sem peir eru á sömu launum sama hversu mikil eftirspurnin er. Petta getur leitt til pess að læknar sinni síður peim sjúklingum sem eru verr á sig komnir af ótta við pað að peir krefjist of mikillar pjónustu á kostnað frítíma læknisins og peim sjúklingum sé pá hugsanlega beint annað. Баð er pví hætta á pví að læknar með fastar greiðslur veiti minni pjónustu en hagkvæmt er (Ellis, 1998).

Í Bandaríkjunum geta sjúklingar valið milli pess hvort peir eigi viðskipti við lækni samkvæmt fastgreiðslufyrirkomulagi, HMO (Health Maintenance Organization), eða kerfis par sem greitt er fyrir hvert unnið verk, FFS (Fee-for-service). Skoðað hefur verið hvaða áhrif hvort kerfi um sig hefur á innlagnir. Í ljós kom að peir sem eru í FFS-kerfinu verja að jafnaði meiri tíma á spítölum en peir sem eru í HMO-kerfinu. FFS-sjúklingarnir eru eldri og fleiri peirra dóu á rannsóknartímabilinu (Dhanani, O’Leary, Keeler, Bamezai, \& Melnick, 2004). Petta er í samræmi við hugmyndina um að FFS-kerfi henti betur peim sem eru veikari, eða pá að peir sem voru veikari sóttu frekar í pað kerfi. Aðspurðir töldu HMO-sjúklingarnir heilsu sína vera almennt góða eða mjög góða en FFS-sjúklingar sögðu heilsu sína vera lakari (Murgolo, 2002).

Ofangreindar rannsóknir mæla heilsu fólks sem valdi sér viðkomandi kerfi, ekki heilsu fólks og kostnaðinn sem pví fylgir, sem afleiðing af kerfinu. RAND Health Insurance Experiment var tilraun til pess að leiðrétta fyrir pessari valbjögun. Par var fólki á tilviljanakenndan hátt vísað á tiltekið kerfi, annað hvort HMO eða FFS og síðan var athugað hvort kostnaðurinn væri áfram minni í HMO-kerfinu. Í ljós kom að niðurstaðan var nánast sú sama, pjónustan við sjúklinga í HMO-kerfinu var minni, legudagar voru um 40\% færri og par af leiðandi var heildarkostnaður minni. Göngudeildarheimsóknir voru pó nokkurn vegin pær sömu milli kerfanna (Manning, Leibowitz, Goldberg, Rogers, \& Newhouse, 1984). 


\section{STJÓRNMÁL \& \\ STJÓRNSÝSLA}

Meira er stundað af lækningum í forvarnarskyni í fastgreiðslufyrirkomulagi en pað var ekki talið skýra muninn á fjölda legudaga heldur er sú tegund lækninga sem er stunduð í fastgreiðslufyrirkomulagi pess eðlis að innlagnir eru ekki jafn parfar og par af leiðandi verður kostnaður við spítalavist lægri (Manning et al., 1984). Раð gæti pó verið að annar og meiri kostnaður fylgi HMO-kerfinu, svo sem lyfjakostnaður eða heimahjúkrun, pó svo að spítalainnlagnir séu styttri (Dhanani et al., 2004).

Erfitt er að segja til um hvort greiðslufyrirkomulagið sé hentugra eða betra fyrir samfélagið og pá að hvaða leyti. Fastgreiðslufyrirkomulagið eins og pað birtist í Bandaríkjunum er ódýrara í rekstri en prátt fyrir pað er mikilvægt að hafa í huga að minni notkun auðlindar býðir ekki endilega meiri skilvirkni (Brockett, Chang, Rousseau, Semple, \& Yang, 2004). Skoða parf hvað sé skilvirkt fyrir pjóðfélagið í heild, ekki bara kostnaðarminnst fyrir einstaklinginn eða tryggingaaðilann, hvort sem pað er hið opinbera, atvinnurekandi eða tryggingafélag á markaði.

Ofangreind umræða miðast aðallega við bandarískt heilbrigðiskerfi, enda á fræðasviðið rætur sínar að rekja til Bandaríkjanna og hefur víðtækasta skoðunin á framboðsdrifinni eftirspurn átt sér stað par. En pó að heilbrigðiskerfið vestan hafs sé að mörgu leyti ólíkt pví sem pekkist á Íslandi, er ljóst að greiðslufyrirkomulag til lækna getur haft mikil áhrif á starfsemi peirra. Slík áhrif geta pó verið mjög aðstæðubundin. Ógerlegt er að gera öllum peim rannsóknum sem gerðar hafa verið á efninu í víðara samhengi tæmandi skil. Pó má nefna að rannsóknir eru til sem byggja á gögnum frá peim löndum sem við berum okkur helst saman við og má par einna helst nefna Noreg (Carlsen, F. \& Grytten, J. 1998; Grytten, J., Carlsen, F., \& Skau, I. 2001; Sørensen, R. J., Grytten, J. 1999, 2000). Pó ber að hafa hugfast að pessar rannsóknir snúa að miklu leyti að heilsugæslulækningum í kerfi hliðvarða (gatekeepers). Dví er ljóst að pað er jafnvel vandkvæðum bundið að yfirfæra rannsóknarniðurstöður frá nágrannaríkum yfir á íslenskan veruleika vegna margbreytileika kerfanna, rétt eins og pað getur verið erfitt að yfirfæra niðurstöður vegna einnar meðferðar yfir á aðra meðferð.

Eftir að ferliverkasamningum lauk settu læknar í auknum mæli upp einkastofur par sem peir fengu greitt í samræmi við unnin verk. Hér eru breytingar á tíðni speglana á LSH samanborið við breytingar á tíðni speglana á einkastofum skoðaðar fyrir og eftir afnám ferliverkasamninga.

\section{Efniviður og aðferđir}

Unnið var með gögn frá árunum 2000-2005. Í desember 2002 ákvað stjórn LSH að sérstakar greiðslur til starfsmanna vegna vinnu við ferliverk yrðu afnumdar og að laun fyrir göngudeildarvinnu á LSH skyldu greidd samkvæmt kjarasamningum viðkomandi starfsstétta. Í pessari rannsókn er pví litið á árslok 2002 sem vendipunkt pví pá var pessi mikilvæga ákvörðun tekin. Hér verður tíðni speglana árin 2000-2002 borin saman við tíoni speglana árin 2003-2005.

Ítarleg gögn fengust frá Landspítalanum við Hringbraut par sem speglanir voru flokkaðar eftir tegundum niður á hvern og einn mánuð yfir tímabilið. Úr starfsemis- 


\section{STJÓRNSÝSLA}

upplýsingum spítalans var pví miður aðeins hægt að fá upplýsingar á ársgrundvelli fyrir speglanir sem framkvæmdar voru í peim hluta spítalans sem er til húsa í Fossvogi. Pessar tölur voru lagðar saman og pannig fengust upplýsingar um heildarspeglanir á LSH. Frá Sjúkratryggingum Íslands fengust tölur yfir speglanir framkvæmdar á einkastofum lækna á tímabilinu og að lokum fengust, til samanburðar, sambærilegar tölur frá Sjúkrahúsinu á Akureyri. Á Akureyri átti engin breyting sér stað í greiðslutilhögun til lækna yfir tímabilið og er Sjúkrahúsið á Akureyri pví notað sem viðmiðunarsjúkrahús. Ferliverkasamningar voru og eru enn í gildi par.

Sýnt er myndrænt fram á áhrifin sem afnám ferliverkasamninga höfou á fjölda speglana á einkastofum, LSH og höfuðborgarsvæðinu alls, auk Sjúkrahússins á Akureyri til viðmiðunar. Berkjuspeglanir fá sérstaka umfjöllun en pær eru dæmi um speglunaraðgerðir sem héldust á spítölunum bæði fyrir og eftir afnám samninganna. Til samanburðar er gerð myndræn skoðun á próun magaspeglana en pær er auðveldara að framkvæma á einkastofum.

Í framhaldinu var reiknuð hlutfallsleg áhætta pess að fara í speglun, óháð tegund speglunar, með pví að skoða tölur um fjölda speglana eftir að stjórn spítalans ákvað аð afnema ferliverkasamninga (2003-2005) samanborið við tölur um fjölda speglana meðan að ferliverkasamningar voru í gildi (2000-2002) að teknu tilliti til mannfjölda á hverjum stað fyrir sig. Ástæða pess að útreikningar voru miðaðir við mannfjölda en ekki læknisheimsóknir var sú að fjöldi heimsókna er samspil af eftirspurn eftir peim og framboði. Breytt greiðslufyrirkomulag gæti hæglega haft áhrif á framboð peirra. Ef speglanir eru ábatasamar á tilteknu tímabili gætu læknar haft hvata til pess að auka móttöku sjúklinga, enda eru pær forsenda speglana. Með pví að nota íbúafjölda á upptökusvæði tiltekinnar starfsemi fáum við pví fram heildaráhrif af breyttu greiðslufyrirkomulagi á læknisstörf og forðumst bjagað mat hlutfallslegrar áhættu vegna ofangreindra áhrifa á nefnara peirra hlutfalla sem mæld eru.

próun speglana á Akureyri er höfð til hliðsjónar með pað fyrir augum að greina mögulega tímaleitni í gögnunum sem ekki kemur til vegna breytinga á greiðslufyrirkomulagi. Ef slík leitni reynist vera til staðar má aðgreina hana frá áhrifum breytts greiðslufyrirkomulags. Pannig má í einhverjum skilningi nálgast mismun mismunar (difference in difference) vegna breytinganna, en ekki einungis muninn fyrir og eftir breytinguna.

Sem nefnara við útreikning á hlutfallslegri áhættu voru gögn frá Hagstofu Íslands yfir mannfjölda 18 ára og eldri á höfuðborgarsvæðinu og í sjúkrahúsumdæmi Akureyrar notuð. Til pess að aðgreina sjúkrahúsumdæmin var stuðst við upplýsingar frá Landlæknisembættinu. Í töflu 1 sést mannfjöldinn eftir árum, annars vegar í sjúkrahúsumdæmi höfuðborgarsvæðisins og hins vegar sjúkrahúsumdæmi Norðurlands ásamt fjölda speglana á Landspítalanum, bæði Hringbraut og í Fossvogi, á einkastofum og á Akureyri. Á tímabilinu var unnið gagngert að pví að færa pessa starfsemi úr húsnæði LSH í Fossvogi yfir í húsnæði LSH við Hringbraut (Landspítali - háskólasjúkrahús, 2004). Pað er pví ekki tilviljun að speglanir lækkuðu hraðar í Fossvogi en á Hringbraut. Dess má pó geta 
að í öllum tilfellum pegar reiknuð er hlutfallsleg áhætta eru pessar tölur lagðar saman og pessi tilfærsla jafnast pví út í útreikningum.

Tafla 1. Mannfjöldi 1. des., 18 ára og eldri og heildarfjöldi speglana eftir landshlutum

\begin{tabular}{|lrrrrrr|}
\hline & 2000 & 2001 & 2002 & 2003 & 2004 & 2005 \\
\hline Mannfjöldi & & & & & & \\
\hline Höfuð̋borgarsvæðið & 128.432 & 131.192 & 132.828 & 134.445 & 135.984 & 138.834 \\
Akureyri og nærsveitir & 22.249 & 22.322 & 22.438 & 22.511 & 22.532 & 22.642 \\
\hline Fjöldi speglana & & & & & & \\
\hline LSH-Hringbraut & 4.241 & 4.380 & 4.430 & 3.243 & 3.376 & 3.548 \\
LSH-Fossvogi & 2.540 & 3.095 & 2.685 & 1.515 & 1.262 & 829 \\
Einkastofur & 1.620 & 1.691 & 1.607 & 4.285 & 5.092 & 5.244 \\
Akureyri & 1.072 & 1.272 & 1.138 & 1.173 & 1.085 & 1.362 \\
\hline
\end{tabular}

Hlutfallsleg hætta á að fara í speglun var reiknuð óháð pví hvort viðkomandi hefði farið áður í speglun. Mannfjöldi á svæðunum sem til skoðunar eru, árin 2000-2002 er pví lagður saman til pess að fá heildarfjölda fólks sem fór, eða fór ekki, í speglun á pví tímabili. Eins er mannfjöldi áranna 2003-2005 lagður saman til pess að finna heildarfjölda fólks sem fór, eða fór ekki, í speglun á pví tímabili. Notaður var tölfræðihugbúnaðurinn MedCalc til pess að reikna hlutfallslegu áhættuna og staðalfrávik.

\section{Niðurstöður}

Mynd 1 sýnir áhrif afnáms ferliverkasamninganna. Í desember 2002 ákvað stjórn LSH að sérstakar greiðslur til starfsmanna vegna vinnu við ferliverk yrðu afnumdar og pá drógust speglanir saman um 33\% á LSH, en jukust um 167\% á einkastofum á næsta árinu. Heildarfjöldi speglana sem framkvæmdar voru á höfuðborgarsvæðinu (LSH og einkastofur) hækkaði örlítið yfir tímabilið. Á mynd 2 má svo sjá hvernig hlutdeild Landspítalans af heildarfjölda speglana lækkaði um leið og hlutdeild einkastofanna jókst. 
STJÓRNSÝSLA

Mynd 1. Próun heildarfjölda speglana árin 2000-2005

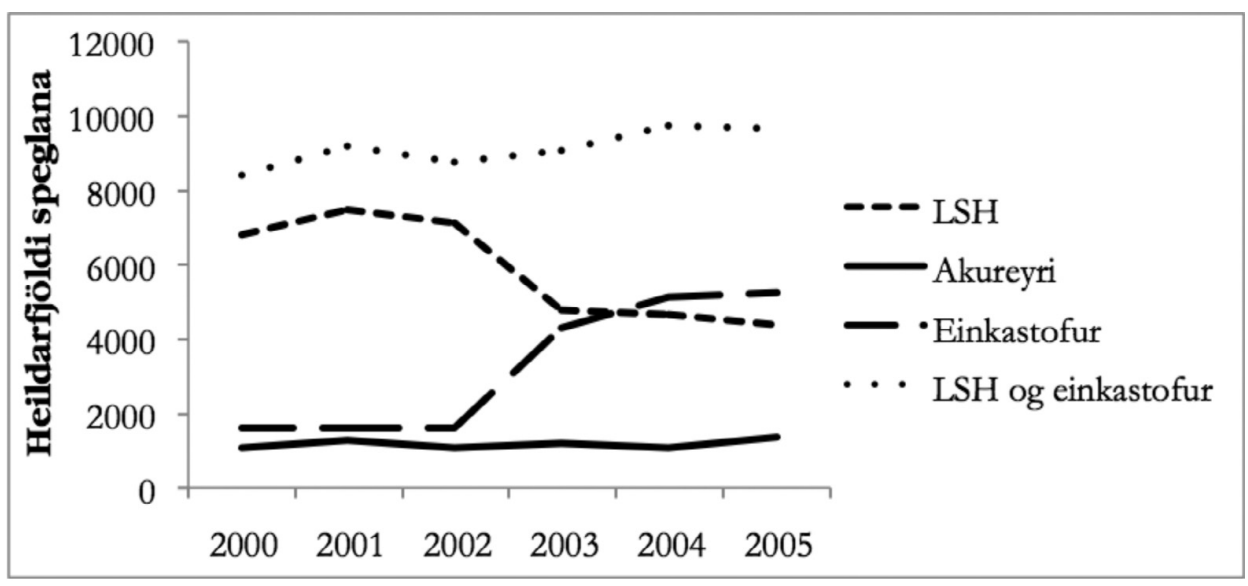

Mynd 2. Hlutdeild einkastofa og LSH af heildarfjölda speglana árin 2000-2005

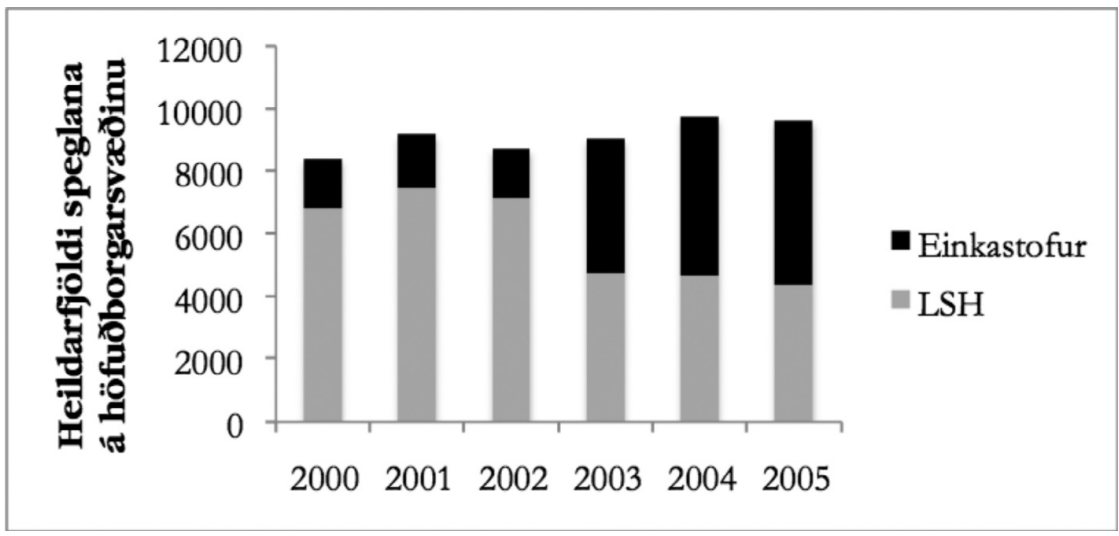

Á mynd 3 sést próun berkjuspeglana. Berkjuspeglunum fækkaði, úr pví að hafa verið yfir 300 á ári meðan að ferliverkasamningar voru í gildi, niður í tæplega 200 á ári, án pess að pær flyttust á einkastofur. Mynd 4 sýnir hins vegar próun magaspeglana sem er dæmi um speglunaraðgerðir sem færðust til og voru gerðar í auknum mæli á einkastofum eftir að ferliverkasamningum lauk. Heildarfjöldi magaspeglana á höfuðborgarsvæðinu jókst eins og myndin sýnir, ólíkt pví sem gerðist með berkjuspeglanirnar. 
Mynd 3. Próun berkjuspeglana á LSH-Hringbraut árin 2000-2005

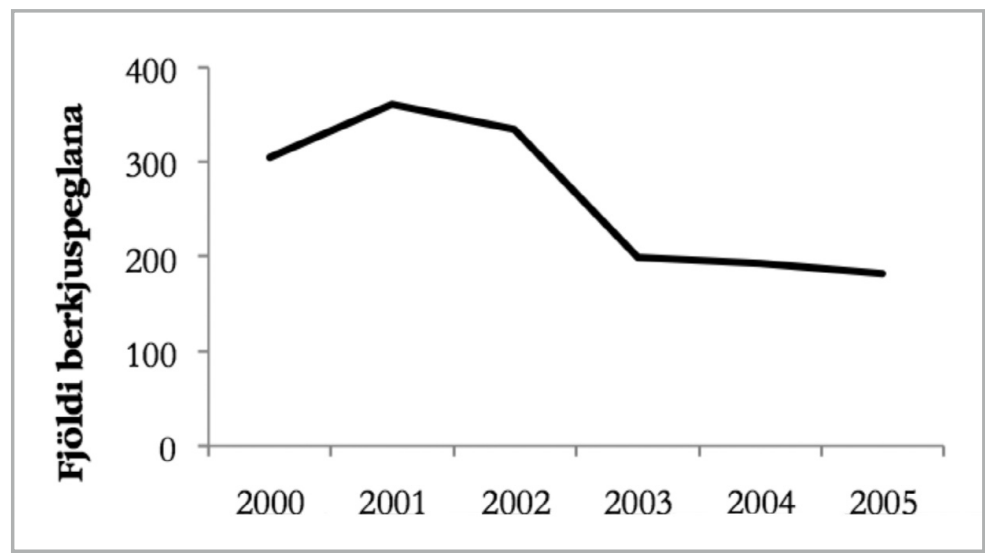

Mynd 4. Próun magaspeglana á höfuðborgarsvæđinu árin 2000-2005. ${ }^{1}$

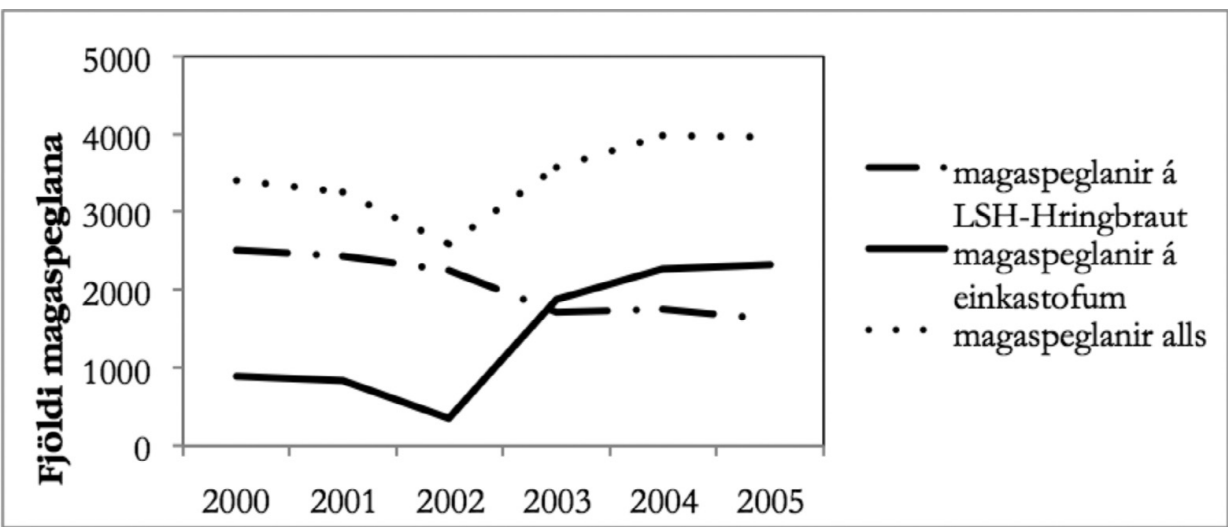

Niðurstöðurnar um hlutfallslega áhættu má finna í töflu 2. •ær sýna að einstaklingar á höfuðborgarsvæðinu voru 185\% líklegri til að fara í speglun á einkastofum árin 2003-2005 heldur en á árunum 2000-2002. Líkurnar á pví að fara í speglun á LSH minnkuðu hins vegar um 38,2\% á sama tíma. Á höfuðborgarsvæðinu jukust líkur á að fara í speglun alls um 3,57\% eftir að stjórn LSH ákvað að afnema ferliverksamninga. Allar niðurstöður sem viðkomu höfuðborgarsvæðinu sýndu mikla tölfræðilega marktækni $(p<0,0001)$. Samkvæmt punktmati i viðmiðunarhópnum, Akureyri, jukust líkurnar á að fara í speglun eftir að ferliverkasamningar duttu úr gildi á LSH um 2,92\%. Dessar niðurstöðurnar eru hins vegar tölfræðilega ómarktækar $(\mathrm{p}=0,2121)$. 


\section{STJÓRNSÝSLA}

Tafla 2. Hlutfallsleg áhætta á að fara í speglun

\begin{tabular}{|l|r|r|r|r|}
\hline & $\begin{array}{r}\text { Speglanir } \\
\mathbf{2 0 0 0 - 2 0 0 2}\end{array}$ & $\begin{array}{r}\text { Speglanir } \\
\mathbf{2 0 0 3 - 2 0 0 5}\end{array}$ & Hlutfallsleg áhætta (95\% Cl) & p-gildi \\
\hline Landspítalinn & 21.371 & 13.773 & $0,618(0,6052$ til 0,6311) & $<0,0001$ \\
\hline Einkastofur & 4.918 & 14.621 & $2,8508(2,7610$ til 2,9436) & $<0,0001$ \\
\hline Höfuðoborgarsvæðið alls & 26.289 & 28.394 & $1,0357(1,0191$ til 1,0526) & $<0,0001$ \\
\hline Akureyri & 3.482 & 3.620 & $1,0292(0,9837$ til 1,0769) & 0,2121 \\
\hline
\end{tabular}

\section{Umræða}

Markmið pessarar rannsóknar var að kanna mun á pjónustu lækna pegar peir starfa samkvæmt fastlaunakerfi til samanburðar við kerfi par sem greitt er í samræmi við unnin störf. Rannsóknin leiddi í ljós að pegar greiðslur fyrir ferliverk á LSH samkvæmt fastlaunakerfi hófust breyttist pjónustan. Í flestum tilfellum færðist pjónustan yfir á einkastofurnar, en í öðrum tilfellum var um fækkun speglana á spítalanum að ræða án pess að aukin pjónusta kæmi til á öðrum stöðum (til dæmis berkjuspeglanir). Matsstuðlarnir eru ekki einungis tölfræðilega marktækir, heldur einnig af stærðargráðu sem skiptir máli í hagnýtu samhengi. Dví er óhætt að segja að afnám ferliverkasamninganna hafi haft áhrif. Starfsemi spítalans færðist að miklu leyti á einkastofurnar og hlutfallsleg hætta á að fara í speglun á höfuðborgarsvæðinu jókst.

раð er pó ekki hægt að fullyrða að hlutfallsleg áhætta hafi einungis aukist vegna pess að ferliverkasamningum lauk. Hlutfallsleg áhætta pess að fara í speglun jókst einnig á Akureyri á sama tímabili og pó svo að matsstuðull peirrar mælingar sé tölfræðilega ómarktækur og minni en matsstuðull höfuðborgarsvæðisins, mætti velta pví fyrir sér hvort einhverjir ytri pættir hafi aukið fjölda speglana á báðum stöðum á tímabilinu. Ef menn vilja gæta ýtrustu varfærni í ályktunum mætti draga áhrifastuðul Sjúkrahússins á Akureyri frá áhrifastuðli Reykjavíkur og horfa til pess sem eftir stendur sem raunverulegra áhrifa afnáms ferliverkasamninga. Peir ytri pættir sem par með væru takmarkaðir gætu til dæmis verið kvillar sem aukist hefðu á pessum tíma og aukið pörfina fyrir speglanir í báđum landshlutum. Umfang pessarar rannsóknar gaf pví miður ekki tilefni til pess að skoða alla slíka hugsanlega ytri pætti.

Svigrúm lækna til pess að stunda læknisverk jókst eftir að ferliverkasamningum lauk og getur pað skýrt aukninguna á hlutfallslegri áhættu. Meðan ferliverkasamningar voru í gildi voru gerðir samningar við hvern og einn lækni um hlutfall vinnunnar sem færi í að sinna göngudeildarverkum og tímarnir sem fóru í pá vinnu drógust frá tímunum sem fóru í að sinna öðrum verkum á spítalanum. Фað var pví í höndum stjórnenda spítalans hve mikið læknar gátu unnið við aðstæður par sem greitt var í samræmi við unnin störf. Eftir að ferliverkasamningum lauk máttu læknar hins vegar vera í allt að 80\% vinnu á spítalanum, samfara stofurekstri sem peir stjórnuðu eftir eigin höfði. Баð er pví hægt að álykta sem svo að læknar hafi getað verið í meira en 100\% vinnu ef peir vildu, eftir að ferliverkasamningum lauk. Aðrir pættir, svo sem ný tækni, styttri biðtími og bætt pjónusta á einkastofum, gætu sömuleiðis hafa ýtt undir pessa aukningu. 
Раð er ekki hægt að fullyrða um pað, út frá pessari rannsókn, af hverju aukning varð á hlutfallslegri áhættu pess að fara í speglun á höfuðborgarsvæðinu og sömuleiðis hvort breytingin var betri eða verri fyrir samfélagið, enda geta bæði fastlaunakerfi og greiðsla eftir verkum leitt til óhagfelldra hvata, hvort á sinn hátt. Miðað við fyrri afkastagetu Landspítalans má pó leiða að pví líkur að aðstaða til speglana á spítalanum hafi verið illa nýtt eftir að ferliverkasamningum lauk og önnur aðstaða utan spítalans hafi myndast, hugsanlega að ópörfu. Að pví leyti var afnám ferliverkasamninga hugsanlega tilfærsla frá hagfelldustu ráðstöfun á aðstöðu til speglana. Spítalinn hafði bolmagn til pess að framkvæma allt að 7.475 speglanir árið 2001 en framkvæmdi einungis 4.377 árið 2005. Pannig má hugsa sér að sóun hafi falist í pví að koma upp aðstöðu á einkastofum pegar hún var tiltæk á Landspítalanum.

Innra réttmæti (internal validity) pessarar rannsóknar ætti að vera töluvert. Dó ber að nefna gæði gagnanna sem unnið var með sem hugsanlegan veikleika, en einn gagnapunktur vakti spurningar um áreiðanleika sem ekki var unnt að sannreyna. Petta var varðandi fjölda magaspeglana framkvæmdar á einkastofum árið 2002. Pær voru óvenjufáar pað árið án pess að nokkur skýring lægi fyrir. Ytra réttmæti (external validity) rannsóknarinnar er ábótavant par sem erfitt er að yfirfæra pessar niðurstöður á aðrar aðstæður innan íslensks heilbrigðiskerfis sem enn eru órannsakaðar. Eðli pessa rannsóknasviðs felur í sér að áhrifin eru aðstæðubundin; mismunandi stofnanagerð og sú tegund pjónustu sem til umfjöllunar er getur breytt niðurstöðum. Pessi rannsókn gefur vísbendingu um áhrif ferliverkasamninga en alls óvíst er hvort sambærileg niðurstaða fengist annarsstaðar í heilbrigðiskerfinu fyrir ólíka pjónustu.

Umfjöllunin um ferliverkasamningana og áhrif peirra varpar ljósi á mikilvægi pess að hanna rétt hvatakerfi pví erfitt getur reynst að stjórna hegðun fólks með tilmælum ef hagsmunir eru ekki í samræmi við pau. Rannsókn sem pessi á áhrifum mismunandi greiðslufyrirkomulags er fyrsta skrefið í pá átt. Hún sýnir einnig að greiðslur til lækna geta verið mikilvægur áhrifapáttur í meðferð sjúklinga. Pessi rannsókn gefur tóninn til frekari rannsókna um afleiðingar afnáms ferliverkasamninga. Í slíkum rannsóknum mætti til dæmis skoða hvort færsla lækna af spítalanum á einkastofur hafi haft marktæk áhrif á heilsu fólks á höfuðborgarsvæðinu. Í ljósi pess að viðbrögð heilbrigðisstarfsfólks við hvatakerfum eru háð umhverfi og aðstæðum í víðara samhengi er mikilvægt að skoða fleiri hvata innan íslensks heilbrigðiskerfis. Slíkar rannsóknir hafa bæði fræðilegt og hagnýtt gildi.

\section{Pakkir}

Sérstakar pakkir fær Jóhannes Gunnarsson, læknisfræðilegur verkefnisstjóri Nýs Landspítala, fyrir gagnlegar upplýsingar og aðstoð.

\section{Aftanmálsgreinar}

1 Athugið аð óvenjufáar magaspeglanir voru framkvæmdar á einkastofum árið 2002. Pær fóru úr 827 árið 2001 niður í 352 árið 2002 og svo upp í 1871 talsins árið 2003. Ítrekað hefur verið haft samband við Sjúkratryggingar Íslands til pess að fá skýringu á pessu en pví miður hafa engin svör fengist. 


\section{STJÓRNSÝSLA}

\section{Heimildir}

Arrow, K. J. (1963). „Uncertainty and the Welfare Economics of Medical Care “, The American Economic Review, 53(5), 941-973.

Brockett, P. L., Chang, R. E., Rousseau, J. J., Semple, J. H., \& Yang, C. H. (2004). „A comparison of HMO efficiencies as a function of provider autonomy", Journal of Risk and Insurance, 71(1), 1-19.

Carlsen, F. \& Grytten, J. (1998). „More Physicians: improved availability or induced demand?", Health Economics, 7(6), 495-508.

Dhanani, N., O’Leary, J. F., Keeler, E., Bamezai, A., \& Melnick, G. (2004). „The effect of HMOs on the inpatient utilization of medicare beneficiaries", Health Services Research, 39(5), 1607-+.

Ellis, R. P. (1998). „Creaming, skimping and dumping: provider competition on the intensive and extensive margins", Journal of Health Economics, 17(5), 537-555.

Grytten, J., Carlsen, F., \& Skau, I. (2001). „The income effect and supplier induced demand. Evidence from primary physician services in Norway", Applied Economics, 33(11), 1455-1467.

Hagstofa Íslands. (2012). „Mannfjöldi eftir byggðakjörnum, kyni og aldri 1. desember 1997-2008“, Sótt 9. mars, 2012 af: http://www.hagstofa.is/?PageID=2593\&src=/temp/

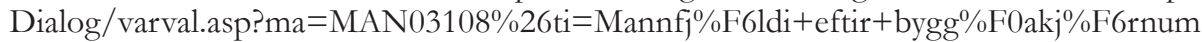
$\% 2 \mathrm{C}+\mathrm{kyni}+\mathrm{og}+$ aldri+1\%2E +desember+1997\%2D2008+++\%26path=../Database / mannfjoldi/Byggdakjarnareldra/ $\% 26$ lang $=3 \% 26$ units $=\mathrm{Fj} \% \mathrm{~F} 6 \mathrm{ldi}$

Landspítali - háskólasjúkrahús (2001). Ferliverk i starfsemi spitalans: Skýrsla nefndar forstjóra. Reykjavík.

Landspítali - háskólasjúkrahús (2004). Ferliverkastarfsemi á Landspitala - báskólasjúkrabúsi: Álit nefndar forstjóra LSH apríl 2004. Reykjavík.

Landspítali - háskólasjúkrahús (2005, 9. desember). „Yfirlýsing frá Landspítala - háskólasjúkrahúsi“, Morgunbladid. Sótt 21. febrúar 2012 af: http://www.mbl.is/greinasafn/ grein/1054432/

Manning, W. G., Leibowitz, A., Goldberg, G. A., Rogers, W. H., \& Newhouse, J. P. (1984). „A Controlled Trial of the Effect of a Prepaid Group-Practice on Use of Services“, New England Journal of Medicine, 310(23), 1505-1510.

Morgunblaðið (2004, 24. janúar). „Helmingur launagreiðslna LSH til lækna og hjúkrunarfræðinga“, Morgunblaðið, baksíða. Sótt 21. febrúar 2012 af: http:/ /www.mbl.is/greinasafn/ grein/777013/

Murgolo, M. S. (2002). „Comparison of medicare risk HMO and FFS enrollees“, Health Care Financing Review, 24(1), 177-185.

Pauly, M. V. (1979). „What Is Unnecessary Surgery? “, Milbank Memorial Fund Quarterly-Health and Society, 57(1), 95-117.

Ríkisendurskoðun (2002). Samningar Tryggingastofnunar vegna sérfrađilakna 1998-2001: Stjórnsýsluendurskodun sjúkratryggingasvids TR. Reykjavík.

Sørensen, R. J., Grytten, J. (1999). „Competition and supplier-induced demand in a health care system with fixed fees", Health Economics, 8(6), 497-508.

Sørensen, R., Grytten, J. (2000). „'Type of contract and supplier-induced demand for primary physicians in Norway“, Journal of Health Economics, 20, 379-393.

The Dartmouth Atlas of Health Care (e.d.). „Medicare Spending“, Sótt 22. febrúar 2012 af: http://www.dartmouthatlas.org/keyissues/issue.aspx?con=1339 